$\triangle$ CTA NEOPHILOLOGICA

UDK: 821.133.1(65).09:305

DOI: 10.4312/an.52.1-2.69-96

\title{
Transing the Algerian Nation-State: Textual Transgender and Intersex from Pre-Independence to the Black Decade
}

\section{Chantal Zabus}

\section{ABSTRACT}

The article examines the role of transgender and intersex in two key-texts, Marie-Pierre Pruvot's Marie parce que c'est joli (2007) and Fériel Assima's Roublem ou le sexe des anges (1996). Both texts chronicle two «moments» in Algerian history: 1) the two decades leading to Algerian independence in 1962; and 2) the Black decade spanning 1988-1998. These «moments» are experienced by two protagonists-pied-noir Jean-Pierre Pruvot and MTF Marie-Pierre Pruvot, rolled into one; and Assima's intersex character raised as a boy, Rhoulem. Both their repressed feminine genders and bodies-in-transition, reflected through the discursive erosion of male genitalia, augur the "transing" of the Algerian nation-state, away from a traditional engendering of the nation-state as male.

Keywords: Transgender, Intersex, Trans(ion)ing, Algeria, Nation-State, queer Maghreb 
On the traditional model of governmentality, Foucault sardonically comments that a good government manages the nation-state in the same way that a good father governs the household and monitors the sexuality of its dependent members (Foucault 2001: 208-209). The art of governing, which claims social coherence and adherence to strict, patriarchal gender regimes, is therefore a pre-requisite for the stability and success of a socially and culturally coherent nation-state. In postcolonial African fiction, the disappearance, absence, impotence or transformation of male genitals, as they embody patriarchy, is often conjured up as an allegory to signify the collapse and failure of the postcolonial nation-state. This is certainly the case in Sub-Saharan African fiction and film, starting with Sembène Ousmane's Xala $(1975)^{1}$. Maghrebi texts are no exception, but some of them come with a twist in that the repression of the feminine in the transgender or intersex protagonist points to a crisis of masculinities in a nation-state such as Algeria that insists on maintaining an exclusively patriarchal type of governmentality.

\section{TRANSING NATIONS}

In his seminal book, Queer Nations (2000), Jarrod Hayes approaches fiction by Maghrebi writers such as Tahar Djaout, Mohammed Dib, Kateb Yacine, Tahar Ben Jelloun, Assia Djebar and Leila Sebar in an attempt to delineate "allegories of the Queer Nation." Using mainly novels to illustrate such allegories on the grounds that nations are fictions supported by narratives, Hayes postulates that when Maghrebi authors represent "homosexuality, sodomy, homoeroticism, lesbianism, cross-dressing, the joys of emasculation, women's resistance, public unveiling, and feminist guerilla warfare, they do not merely challenge sexual taboos, sexual normativity, and patriarchy (which they do), they also reveal the queerness of the Nation" (Hayes 2000: 16). Building on such a premise, this study holds that at least two Francophone Algerian texts foregrounding transgender and intersex focus, in varying degrees, on the erosion or questioning of orthodox sexual and gender paradigms. In the process, they point to cracks in the making of the heteronormative postcolonial nation-state to the point of transing the nation.

1 This is also illustrated in Souleymane Cissé's Yeleen (1987); Benoit Lamy and Ngangura Mweze's La vie est belle (Life is Rosy) (1987), Jean-Pierre Bekolo's Quartier Mozart (1992) and science-fiction film Les saignantes: A Story of Corruption, Sexuality, and Supernatural Power (2005), previewed during the 2005 Toronto International Film Festival (TIFF) and translated as The Bloodettes. 
Transing is part of new vocabularies associated to transgenderism (TG) and transsexualism (TS), ${ }^{2}$ i.e. the transitioning from the birth sex to the targeted gender identity, usually but not necessarily through sex reassignment surgery (SRS), also called gender confirmation surgery. Transing is here extended to intersexuality, generally understood as a condition of gonadal or external genital ambiguity. The notion of transing reflects a necessary process of transcending and "transpassing" (Najmabadi 2008) across Algeria's sex/gender walls and other patriarchal scaffoldings.

The consequences of the Algerian war which culminated in the independence of Algeria in 1962 has been equated with a festering wound, a long-lasting trauma waiting to be re-invoked in order to be turned into a healing memory. Yet, according to Franco-Algerian historian Benjamin Stora in La Grangrène et l'oubli, this healing had not yet been properly processed in the late 1990s; Stora used very apt phrases_-"une guerre ensevelie, [...] oubliée [...] intérirorisée" (Stora 1998: 238) - to refer to the collective amnesia unfolding in stages and culminating in an internalized war. Stora has since moved away from such an introspective reading. In a Conference at the Institut français d'Alger on 3 December 2018, Stora evoked the necessity of transcending "mourning" and the role of culture during the post-mourning process in healing breaches between France and Algeria while questioning the aptness of the family metaphor used in a TV documentary significantly titled "France/Algérie: une histoire de famille" broadcast on 29 November 2018 by public TV channel France $2 .^{3}$

Taking her cue from Stora in La gangrène et lmoubli, Helen Vassallo has diagnosed Franco-Algerian novelist Nina Bouraoui's autobiographical writing as reflecting the waging of the war between Algeria and France within the sexually dissident body (Vassallo 2009: 39), particularly in the years following the conflict and its ongoing legacy. In Garçon Manqué (2000), translated as Tomboy (2007), Bouraoui, whose father is Algerian and mother French, writes: "Je viens d'une union rare. Je suis la France avec l'Algérie»; «Je viens de la guerre» (Bouraoui 2000: 9 \& 32). Additionally, Bouraoui's male cross-dressing as a young girl, according to Vassallo, reveals her escape from "the confines of a stereotypical feminine model

2 By "transgender (TG) individuals," we refer to individuals ranging from a) "non-operative" individuals who often live and identify as belonging to a sex different from that assigned at birth and who may or may not cross-dress; to b) individuals who consider themselves a "third sex" or "Two-Spirit" and cultivate a certain, often culture-specific, gender liminality (genderqueer) to the point of resisting the predominant view of gender categories as a male/female binary; and to c) transsexual individuals (transmen and transwomen) who have changed their bodies through sex reassignment surgery (SRS), also called gender confirmation surgery. The term "transsexualism" was first used in its modern sense by Cauldwell (1940) and elaborated in the clinical literature by Benjamin (1966).

3 http://lesavoire.over-blog.com/2018/12/benjamin-stora-au-sujet-des-relations-algero-francaises-la-culture-pour-depasser-le-deuil.html. Accessed on 28 February 2019. 
only to embrace a stereotypically masculine one" (Vassallo 2009: 43). Tomboy indeed features a cross-dresser, but that cross-dresser is also a transgender character in that the female-born I-narrator takes on a full-fledged and even double male identity as "Ahmed" or "Brio." Such a transgender character opens the portal to Francophone FTM (Female-to-Male) narratives, for most contemporaneous Francophone novels still tend to privilege MTF (Male-to-Female) narratives, from Eric Fottorino's Caresse de rouge (2004) to Juliette Jourdan's Le choix de Juliette (2009) and Jean-Noël Sciarini's Le garçon bientôt oublié (2010). ${ }^{4}$

A few Moroccan writers like Abdelkebir Khatibi and Abdelhak Serhane have alluded to some aspects of transgenderism..$^{5}$ More recently, Moroccan Abdellah Taïa, who, in Une mélancolie arabe (2008), had already recounted his tribulations as a queer child, features, in Le jour du roi (2010), one boy Omar, who has put on lipstick and declares: "Je ne suis ni garçon, ni fille.Je suis dans le désir" (Taïa 2010: 179). Taïa had confided in 2008 to Rabat-based sociologist Jean Zaganiaris that he wished, in his writing, to go "au-delà de l'hétérosexualité et de l'homosexualité ... vers le transgenre, la transformation" (Zaganiaris 2008: n.p.) but Taia's will to move towards transgender remains thus far a metaphor within a same-sex libidinal economy.

In one of his short stories, "J'aime les filles" (2013), Moroccan Hicham Tahir chronicles a love story between two Moroccan female teenagers, Ghizlane and Niaama. Niaama reasons that, even though she is attracted to Ghislane, she does not think of herself as «homosexual»: «Etre homosexuelle impliquait que je devais être attirée par les femmes, mais je ne l'étais pas, aussi difficile de le croire, je ne l'étais pas. J'étais attirée par Ghizlane et Ghizlane seule" (Tahir 2013: 54). Niaama's statement could be read as emanating from an FTM character who desires a female partner as a transman or at any rate as a non-operative transman, that is, a transgender individual who has not undergone sex reassignment surgery. This would explain why Niaama considers hirself $f^{6}$ as not falling into the "homosexual" category. However, Ghislane confirms the same thing- "ni les garçons ni les filles nétaient sa tasse de thé" (Tahir 2013: 54) —and therefore locates hir desire outside of the homosexual/heterosexual divide, in a multigendered perspective. Beyond this hint at a variant of transgender verging on a non-binary or genderqueer perception of masculinity and femininity, Tahir's surrogate character, in another short

4 For a list of transgender novels, films and documentaries in French in the first decade of the twenty-first century, see Todd Reeser, "Introduction," p. 2 ff.

5 Already in Le livre du sang (1979) Moroccan sociologist Abdelkebir Khatibi had portrayed androgyny but more in an eighth-century Sufi sense than in the contemporary understanding of transgender. Morrocan Berber novelist Abdelhak Serhane in Messaouda (1983) describes the eponymous prostitute as a "solitary hermaphrodite" (Serhane 2002: 43, 45, 11).

6 Hir and hirself are third-person, gender-neutral or multigendered pronouns resulting from the rise of transgender theory. 
story, "Assim," dreams of resorting to aesthetic surgery and of cultivating doubt as to his gender: "Laisser le doute planer chez les gens à se demander si je suis un homme ou si je suis une femme" (Tahir 2013: 44). But unlike texts dealing with Algeria, these Moroccan texts seldom engage with and confront the body politic. The reason may lie in the fact that more so than other Maghrebi countries, Algeria has been more intricately enmeshed in the recent history of the rise of Islamism.

This study relies on two texts in order to account for the internalizing of the Algerian war, its aftermath, and the inscription of political turmoil onto the bodies of gender non-confirming individuals: Marie-Pierre Pruvot's Marie parce que c'est joli (2007) and Fériel Assima's Rhoulem ou le sexe des anges (1996). These two texts feature, respectively, transgender and intersex protagonists and chronicle two textual moments: the first "moment" covers the 1940s up to independence in 1962; the second "moment" occurs during the décennie noire or Black decade (1988-1998). Despite being "fictive," both texts host degrees of autobiographical or testimonial vestment and feature cross-dressing, stealth or transgender passing in the targeted gender, as well as transsexualism. They both feature a birth and, as is often the case with transgender, transsexual, and intersex characters, their "failure" to fit into prescribed gender (and genital) categories points to tensions in Franco-Algerian relations and in the erection of the new Islamic nation-state.

\section{BAMBI'S MIRROR BIRTH, AMNESIA, AND EARLY SEXUAL CITIZENSHIP}

Marie-Pierre Pruvot, née Jean-Pierre Pruvot (1935-), also called Marie-Pier Ysser (after Isser, the Kabyle village where she was born) and known under her former stage name Bambi, remains the most famous transsexual woman alive in present-day France. Marie parce que c'est joli (2007) is Marie-Pierre Pruvot's first memoir out of many such rehearsals, including the first of five volumes, J'inventais ma vie (2010), and the 2013 Lifshitz documentary. The aim in this section is to link some of her early writing with nation-building in Algeria where she grew up and, accessorily, Morocco, where she was among the first patients of Dr. Burou, who carried out among the first MTF (male-to-female) surgeries in his transgender clinic in Casablanca as of the 1950s.

In Marie parce que c'est joli, which Pruvot conceived as a fictional biography ("biographie romanesque"), she recounts her life or rather the life of Jean-Pierre Pruvot, in colonial Algeria as of the 1940s. Jean-Pierre Pruvot is a pied-noir, that is, an individual of European origin, who lived in Algeria

7 "Failure" is here understood in the positive way in which Halberstam understood it in The Queer Art of Failure (2011). 
under French rule. Unlike Muslim Algerians dispossessed of French citizenship rights, ${ }^{8}$ pied-noirs had voting rights in France and were part of French nationals of either sex in the French Constitution of 1958. As a pied-noir, Jean-Pierre Pruvot thus enjoyed a seeming state of empowerment in colonial Algeria. However, the reader is soon introduced to cracks in that discourse of colonial empowerment through the young Jean-Pierre's wrestling with his first name and his tendency to cross-dress in what might be described as an inaugural "birth" scene. This form of cross-dressing reverses Bouraoui's; yet is, like Bouraoui's, inscribed within a quest for subjectivity and agency in a (post-)colonial Franco-Algerian context.

Jean-Pierre Pruvot's questioning of his male first name and the inaugural scene of cross-dressing occur while growing up at his paternal grandmother's place in Bordj-Menaiel, a little town between Algiers and Tizi-Ouzou, in Western Kabylia, Northern Algeria. Jean-Pierre Pruvot's present-day first name-Marie-Pierreis a concession to his mother's initial choice-"Marie parce que c'est joli," as in the title of Pruvot's fictional memoir, and an endorsement of his father's preference: "[il] penchait pour Pierre" (Pruvot 2007: 9). In one harrowing moment, the mother, who has been worrying about Jean-Pierre wearing girls' dresses, coaxes her son into confessing his "real," hyphenated name amidst choking sobs and hiccups — "Jean-Pierre" (Pruvot 2007:9) — in a proleptic gesture of "deadnaming" her son. The mother indeed has her son entrench his birth name as part of his gender identity, that is, the "deadname" which the older Marie-Pierre will discard to suit her targeted gender.

Jean-Pierre's humiliating confession of his birth name is preceded by a scene of cross-dressing with his older sister's hand-me downs, which signals his first fumbling attempts at recuperating his gender identity as a girl as of the age of four and a half. In this scene, Jean-Pierre sees his true female self in the mirror of his sister's wardrobe, as he is trying on his sister's European-style, imported red dress with little white dots: “...je pus enfin me voir dans la robe rouge à petits points blancs. Ce fut un éblouissement, comme toutes les fois où la tante Sophie, après s'être amusée à me maquiller, me retournait, pour que je m'admire, vers le miroir de son lavabo, et me disait : 'Oh ! la jolie petite fille! '" (Pruvot, 2007: 6). In trans writing, the mirror is customarily linked with the autobiographical genre and with the Lacanian mirror-stage passage from the pre-linguistic Imaginary order to the Symbolic stage of language acquisition. Even though the latter aspect lies beyond the scope of the present article, it is worth noting that Pruvot's mirror birth is resonant with prior mirror-scenes in which his aunt Sophie had made up his face and had exclaimed on his behalf-"What

8 On Algerian Jews, the Crémieux decree and its repeal, see Aron (1976). 
a pretty little girl!," in an endorsement by a female family member which he here recuperates for himself.

In an early, pioneering book theorizing written trans autobiographies, Second Skins (1998), Jay Prosser points to his involvement as an FTM (female-tomale transsexual) with reading other trans individuals' autobiographies: "I am not uninvolved: reading autobiography is always a pointed engagement of the self, and these texts on several levels constitute my mirror-scene" (Prosser 1998: 103). All mirror-scenes, including recent "screen births" in vlogs, ${ }^{9}$ can therefore be read as interchangeable for all trans individuals. At this pre-Internet stage, Jean-Pierre's assessment of his targeted self as female in the mirror is crucial in confirming gender identity processes and in launching a form of what Gayle Rubin has termed "sexual migrancy" (Rubin 1993: 24) on account of his later migrating to Paris and his shuttling between France and Algeria because of his transgender identity.

While auguring contemporary screen births, Pruvot's mirror vignette also harks back to earlier processes, such as in French Belle Epoque traveler and explorer Isabelle Eberhardt who moved to Bône (Annaba), Algeria in 1897, converted to Islam, cross-dressed, and gradually adopted a masculine, Muslim identity, including a changed name. Her subsequent marriage to an Algerian man enrolled in the French military, her role as a free-lance advisor to the colonial authorities in the Sud-Ornais territory, her death in a flash flood in Ain Sefra and the recovery of her body with her Arab cavalryman garb still on are the usual ingredients that make up her legend. Eberhardt's cross-dressing as of an early age and name change to Si Mahmoud Essadi-oddly anticipating, albeit contrapuntally, Alexandra Cerdan's Transsexuelle et convertie à l'Islam (2010)—unwittingly reflects on the mirror scene in which Jean-Pierre/ Marie-Pierre sees hirself as a girl dressed like her sister in a European-style alluring dress at a time when the French standard of femininity in the colonies was strictly codified. In the sense in which Eberhardt's cross-dressing is also a misogynistic reinforcement of colonial patriarchy, she provides the almost photographic negative of Jean-Pierre growing up as a transgender pied noir boy in a feminized, subjugated and weakened Algeria and of Bambi's future legend in the Parisian cabaret culture of the early 1950s.

Against similar lines of refraction, Jean-Pierre Pruvot's snapshot recalls a previous scene from Radclyffe Hall's The Well of Loneliness (1928), in which the protagonist Stephen Gordon tears off her (female) dress in an inverted mirror-scene and, ultimately, expresses a sense of pity for the poor lost materiality of the body

9 On the use of YouTube as a publishing platform for self-staging or what is referred to as "screen birth," see Raun (2016). Tobias Raun argues that "the vlog works as a mirror, a diary, an autobiography, and a vehicle of artistic creation and intervention [...] (and) as a kind of DIY therapy [...] oriented towards a confession" (Raun 2016: 19, my italics). 
and dress, of both the dressed and naked body (Hall 1928: $72 \& 187-188)$. As in Hall's The Well, "the slippage from dress to self" (Prosser 2001:136-137) occurs in Marie but the dress here confirms the self. The difference between acceptance and non-acceptance of the transgender individual's split between sex and gender in both works lies in the way the mirror helps decrease or increase the difference between the reflection of the image and its mental projection of the body image or its phantom morphology. Unlike Stephen Gordon (and, to some extent, Radclyffe Hall), Marie-Pierre Pruvot sees a congruence between Jean-Pierre's reflected image and Marie-Pierre's body image in the polka-dot dress because of the congruence between Jean-Pierre and the author of Marie parce que c'est joli, which projects, albeit timidly, the possibility of transition and a phantom sexual citizenship in France. Marie-Pierre Pruvot's mirror-scene triggers off a disdain for the Algerian birth place which acts as an embarrassing reminder of the despised birth sex and prompts her to leave Algeria. Like Radclyffe Hall's move across the Channel, Jean-Pierre's transnational move to Paris is part of migrating flows, which, at the time, had not yet interacted with advanced sexual cultures to constitute what J. Binnie has termed a "transnational sexual citizenship" (Binnie 1997: 237).

Pruvot's birth scene in Marie parce que c'est joli significantly takes place against the tormented canvas of the Second World War and the conspicuous absence of Pruvot's father who is enlisted in the French forces. Jean-Pierre's father is thus conveniently away at war, as his garrison is stationed in Ouargla, in the Algerian South. Jean-Pierre is thus raised, along with his older sister, by their mother and grandmother in a quintessentially female environment until his demobilized father returns to Bordj-Menaiel in 1940 in time for Jean-Pierre's fifth birthday. He brings back to his daughter-Jean-Pierre's older sister-a doll made of bran which represented a traditional Berber woman with a transparent veil on her hair and glittering sequins adorning her forehead, her wrists, and ankles whereas he gives his son, Jean-Pierre, a Tuareg doll clad in purple cloth, without any sequins or jewels: "un poupon de son qui était censé représenter un touareg, entièrement vêtu d'un tissu violet, sans sequin ni bijou, rien, comme toujours, exprès pour me dire : 'Tu es un garçon"' (Pruvot 2007 : 16). Jean-Pierre therefore attempts to modify the doll's virile sobriety by removing what he deems to be the hideous clothes sown onto the doll's body and thereby rejects his father's not so hidden agenda of confirming his son's gender identity as masculine.

Besides, this scene, which involves using a pair of scissors to destroy the male Tuareg doll, augurs Marie-Pierre Pruvot's later passing under the knife, that is, her MTF sex reassignment surgery in Casablanca, Morocco, where the blade is turned against her, yet is put under erasure in Marie parce que c'est joli. Additionally, the incident involving the destruction of the Tuareg doll by a transgender pied noir child is an eye-opener for understanding the enmeshing of two minority 
discourses: transgender discourse (and its wrestling with non-transgender or cisgender ${ }^{10}$ discourse) and the colonial domination of ethnic minorities- the Berbers and the Tuaregs - by the Arabs, themselves dominated by the French in a two-tiered colonial hierarchy. "On balaya la guenille avec le son" (Pruvot 2007: 16). With the rag being swept away, along with the bran inside the doll, one could conclude: "End of story." Yet, the "story" has only just begun. The transformation of the male doll into a shapeless rag, which lies dejected and thus acts as an enactment of Jean-Pierre's loathed and discarded birth sex, follows upon the inaugural scene of self-mirroring.

Jean-Pierre's birth scene in the mirror at age five coincides with his father's return to Bordj-Menaiel in June 1940, following a decree stipulating that the French military, who were not prisoners in Germany, would be sent back to their families (Pruvot 2007: 14). Like the resulting split in Jean-Pierre's sex/gender identity, France is divided into occupied and non-occupied territory. Algeria was indeed at the time part of the non-occupied Vichy government (July 1940-September 1944), which was a German puppet régime headed by Field Marshall Pétain. In November 1942, Algeria became free from German control : «En novembre 1942, ce fut le débarquement américain en Afrique du Nord. L'Algérie était 'libérée" (Pruvot 2007: 22). In turn, as Moshe Gershovich argued, "the liberation of North Africa by Allied Troops in November 1942 enabled the French military there to switch its allegiances away from Marshall Pétain's collaborationist Vichy Government and to resume active participation in the war against Nazi Germany" (Gershovich 2003: 51). In 1942, that is, two years after the inaugural mirror-scene, Jean-Pierre, who is now six and a half, is thus introduced to the antonymic vocabulary of liberation and collaboration, and is forced to attend a school for boys set up by French minister of public instruction, Jules Ferry, who implemented a set of laws establishing free and mandatory education under the Third Republic (1870-1940) and was in favor of French colonial expansion overseas. The boys were groomed to become the cisgender, active, political citizens of a Renanesque nation of "great men" (Renan 1990: 19), who are responsible for making History.

In this His-story, Algeria was to be part of a geopolitically larger France. Yet, the very transgender status of Jean-Pierre at this stage, his dropping out of school, and his later embracing sex reassignment surgery in Morocco, topple the somatechnological interrelation between individual corporeality and the body politic, which, in its Hobbesian understanding, is conventionally gendered male. ${ }^{11}$ In $L e-$

10 Cisgender is a term from modern endocrinology to refer to non-transgender individuals, that is, individuals who experience a congruence between their gender identity and the sex assigned at birth or birth sex.

11 By "Hobbesian," reference is made to Hobbes 1651: 81-82. In Leviathan, Thomas Hobbes writes: "by art is created that great leviathan called a commonwealth or state ... which is but an artificial man; 
viathan (1651), Hobbes indeed imagined a natural contiguity between the body of "man" and the anatomy of the body politic. ${ }^{12}$ Pruvot's "occupied," divided, transitional body in Marie parce que c'est joli is clearly post-Hobbesian in that it disturbs the safe gendering of the body politic as male at a time when Algeria is starting to resist absorption by a masculinized, Leviathanesque French nation-state.

When Marie-Pierre moves to Paris at age eighteen (in 1953; a decade or so before Algerian independence), she prefigures the wave of pied-noirs-Stora numbers 930, 000 of them (Stora 1998: 259)—who returned to France after independence. Unlike most "transnational" pied-noirs who returned to France with a sense of "remorseless" belonging and "nostalgeria" (Stora 1998: 257 \& 239), Marie-Pierre Pruvot, who is still officially Jean-Pierre, enters France through the back door of Parisian cabarets travestis. Even if her life is studded with glittering moments when performing as a woman at Chez Madame Arthur and then at the top-notch Carrousel, where she as Bambi was headlining beside the famous Coccinelle (Jacqueline Charlotte born Jacques Charles Dufresnoy), she leads a precarious life. She lives almost exclusively by night in Pigalle, Paris's red-light district, and the low-down Boulevard Clichy, in fear of police checks. Indeed, her état civil does not correspond to her gender, an incongruence which acts as a pointer to the legislative force of the French nation-state.

Most Parisian pre-operative transwomen in the 1950s and 1960s received their hormonal tablets over the counter in local Pigalle pharmacies, without medical control (Lifshitz 2013: $13 \mathrm{~min} 22 \mathrm{sec}$ ), and were often financially dependent on some well-off men so that it can be conjectured that these transformistes - also called by the French tell-tale phrase folles - despite the wigs, the sequins, and the boas worn on stage, lived dismal lives and often experienced a form of gilded prostitution. The travestis most recurrent fear was that of imprisonment, which was used to toughen them up and "masculinize" them, short of "exterminating" them altogether (Pruvot 2007:113) at a time when French law forbade men from wearing feminine clothes except during Carnival time. ${ }^{13}$ At that point in time, Jean-Pierre is assimilated to a travesti, that is, a male cross-dresser, much to Marie-Pierre's chagrin, as she relays in the Lifshitz documentary (2013: 16 min 24 sec). In late-1950s France, Marie-Pierre Pruvot's transnational and transitional body, rolled into one, was thus assimilated to

though of greater stature and strength than the natural, for whose protection and defence it was intended: and in which the sovereignty is an artificial soul, as giving life and motion to the whole body."

12 Stryker and Sullivan, taking their cue from Foucault (Foucault 2003: 265-266) have intuited, in their discussion on self-demand amputation, that "a society within the nation-states of Eurocentric modernity is not an orderly arrangement, structured like an organically integrated social body" (Stryker and Sullivan 2009: 50)

13 See Bambi's official website : www.bambi-officiel.com/cabarets-mythiques-et-personnages-celebres/lhommage-a-coccinelle-par-bambi; see also Espineira et al., p. 78 ; and Foerster, passim. 
a transgressive body which, unless it is hidden in the nocturnal subculture of Parisian cabarets, threatens the sexually, racially, and morally "pure" and amnesic French nation-state, which refused to recognize its Others.

By her own reckoning, Marie-Pierre Pruvot, who ran the risk of being asked to do her military service as Jean-Pierre, saw her involvement with the Algerian war at a safe remove. Even though the euphemistically called événements d'Algérie, which masked France's fear of an Algerian independent nation-state and the definitive end of the Renanesque project, were rapidly unfolding, Bambi saw History stagnate-"Je voyais l'Histoire stagner" (Pruvot 2007: 184). The seemingly insouciant Marie-Pierre, who heard about the National Assembly giving full powers to General De Gaulle in 1958, fell into a torpor: "Je m'endormis sur ses lauriers" (Pruvot 2007: 184). However, despite the dreamy quality of her account, her Algerian relatives, facing forced exile and camping in her mother's flat, are said to be "abattus et désespérés. Vaincus... trabis" (Pruvot 2007: 216; italics in original). Her torpor, it turns out, does not quite obliterate her possible resentment since the pied-noirs, who had supported De Gaulle's return to power, were disappointed that he had failed to uphold colonial rule and instead paved the way to granting independence to Algeria. On Bambi's official website, Marie-Pierre Pruvot expresses regrets about staying away from the Algerian war: «Je me suis tenue à l'écart de la querelle de la Guerre d'Algérie. ${ }^{14}$ » Later, she amply made up for that political void in France, ce serait aussi un beau nom (2011). With its echoes in its concern with renaming, as in Marie parce que c'est joli, the book takes up the history of France (and its entanglements with Algeria) from the end of World War II and the Fourth Republic (1946-1958) to the 2000 London protocol.

Although suspect, Marie-Pierre's slipping into an almost catatonic state in Marie parce que c'est joli illustrates the amnesia characteristic of what Stora called la guerre intériorisée, here experienced from the perspective of a transgender piednoir at a liminal intersection between dominance and disempowerment. This amnesiac state complicates the salutary recall of trauma, however delayed and "unclaimed," after Caruth's apt phrase (Caruth 1996). It is indeed amidst such political upheaval that Jean-Pierre Pruvot returned to Algiers, where the Algerian authorities granted him, without an exequatur procedure, his gender change to "Marie-Pierre Pruvot, born female," after he had undergone sex reassignment surgery in 1960 at Dr. Burou's Clinique du Parc in Casablanca, two years after Coccinelle.

These (mostly MTF) surgeries in the late 1950s and early 1960s were to initiate a fluid trail of "Coxes," after "Coccinelle" in Burou's parlance, in crossing

14 This can be found at: https://www.bambi-officiel.com/tout-sur-bambi. Accessed 14 September 2018. 
borders between Morocco and France, as well as other European countries. ${ }^{15}$ Against a charged political canvas, which involved the exiled Sultan and future King Mohammed V's return in 1955 and Morocco's independence in 1956 following anti-French rioting, Morocco, almost incongruously, acted then as a haven of transsexual or TS transitioning. This early form of transnational "crossing" also initiates the gradual untangling of many gender "conundrums," after British FTM Jan Morris's famous, semi-Orientalist autobiography, Conundrum (1974; reed. 2002). Morocco has since moved from being what Cerdan termed "the hub of transsexuality" (Cerdan 2010: 112) to its present-day function as a "pre-Europe," in Hicham Tahir's words. In Tahir's short story "Mama Africa" (Tahir 2013: 19), Morocco is a nation-state where the Sub-Saharan immigrant refugee "transitions" before reaching the targeted European country.

"We forget we forgot," as Nietzsche memorably remarked (qtd Carver 1998: 21). The silencing of Bambi's surgery in Pruvot's autobiographies $(2007,2010)$ and in the 2013 Lifshitz documentary, ${ }^{16}$ where Marie-Pierre Pruvot puts it under erasure between the outbound flight to Casablanca and the inbound flight to Paris, is however amply made up for in Maghrebi fiction. In Au bonheur des limbes (2006), Moroccan Mohamed Leftah portrays Jeanne the transvestite's newly created vagina after her body was mutilated with acid and glass : «elle y a cisaillé (dans son corps) avec l'acide et le verre, la béance centrale de la féminité, en donnant l'une des formes les plus pures de la géométrie, le triangle équilatéral sphérique [...]. Elle a travaillé sur le rêche, l'anguleux, le pointu [...] Femme réalisée, elle allait jouer le simulacre de la femme» (Leftah $2006: 69-70)$. The "central void of femininity" thus created after "work" on the "angular" and the "pointed" evokes a penectomy whereas the resulting geometrical patterns-the ultimate "spherical equilateral triangle" - recalls Burou's medical sketches detailing the invagination of the penile skin and the resulting vulva. ${ }^{17}$ On the other hand, the "simulacrum of womanhood" during Jeanne's travesti performance obliquely conjures up the French cabaret culture of the late 1950s.

Pruvot devotes one laconic paragraph to her sex reassignment surgery whereby the "mirage" of embodied femaleness at long last materializes, and one paragraph to the debacle of French Algeria as of 1958, which she experienced as in a dream- "comme dans un rêve" (Pruvot 2007: 215). Significantly, Pruvot uses

15 See the role of Belgium in Michiel Van Erp's documentary I am a Woman Now (2012) in which a Belgian transwoman attempts to locate Burou's clinic where she stayed in the early 1970s. Note that it is today a building occupied by a Xerox company. Conversely, Ghent Ziekenhuis in Flanders, Belgium now reads more like a haven for French transgender individuals, among other Europeans.

16 April Ashley is more explicit in her Odyssey: "I've just been born.... I am a woman in Casablanca and I'm in agony but my spirit is soaring" (Qtd Ashley \& Fallowell 1982: 88).

17 http://ai.eecs.umich.edu/people/conway/TS/Burou/Burou.htm. Accessed 22 February 2019. 
the word "mirage," an optical phenomenon in which light rays bend to produce a displaced image of distant objects, to refer to her self-imaging as a female. Equally significantly, that displaced image gets materialized when the material events of the Algerian war and its consequences - forceful displacement-fade out in the distance in her narrative. In The History of Forgetting Norman Klein defines "selective forgetting" as a literary tool for describing a social imaginary: "how fictions are turned into facts, while in turn erasing facts into fictions"(Klein 1997: 16). Using Klein, Judith (now Jack) Halberstam argues in The Queer Art of Failure (2011) that "forgetting allows for a release from the weight of the past and the menace of the future" (Halberstam 2011: 83). Marie-Pierre's memory loss, which enacts Stora's internalized war, as previously argued, is therefore also an opportune form of amnesia which denies the colonial past. Memory loss is, however, necessary to confirm that France can be "imagined" (Anderson 1983: 10; Bhabha 1990: 2) as a nation detached from Algeria, and Marie-Pierre as severed from her colonial past as a pied-noir male.

Marie parce que c'est joli ends on a note of social success as the older Marie-Pierre graduates from the Sorbonne and, in 1974, takes up a job as a teacher in a lycée in the suburbs of Paris, where no one suspects her previous life as Bambi, let alone her status as a transwoman, which she only revealed long after she retired from her position with the French Ministry of National Education.

In both Marie parce que c'est joli and her second autobiography J'inventais ma vie (2010), which details Général de Gaulle's plan for a Renanesque grande nation extending from Dunkerque to Tamanrasset (Pruvot 2010: 176) and the subsequent dissolution of French Algeria, Pruvot bypasses the gruesome and gory police repression of the Algerian demonstrators for Algeria's independence in Paris on 17 October 1961. These events were repressed from France's collective memory for thirty-eight years (if we take the Parisian Head of Police Maurice Papon's court hearing in 1999 as a watershed date), until the French General Assembly transformed les événements d'Algérie into the Algerian war for Independence. The 1961 incident turned massacre was not officially recognized by France until October 2012 when then French President François Hollande officially apologized for the senseless carnage and none other than Benjamin Stora helped him write his apology.

On 16 May 2009 Roselyne Bachelot-Narquin, the then French Minister of Health and Sports, made the announcement that she had consulted with the HAS (Haute Autorité de la Santé) in order to publish the (2010-125) decree officially declaring that transsexualism-les troubles précoces de l'identité de genre known under the French acronym TIG - was to be removed from the DMS manual of mental illnesses, identified in French as ALD, that is, "affections psychiatriques de longue durée." National and international media as well as organizations like 
IDAHO reacted to this ministerial decision suggesting that France was the first country to destigmatize transsexuality so openly. The irony of a French initiative intended to de-pathologize transsexualism was forgotten in the fervor to relay the announcement. Ever since Jacques Lacan, the father of French psychoanalysis, declared in a 1971 seminar that transsexuals confused the sexual organs with the signifiant- "C'est en tant que signifiant que le transsexualiste n'en veut plus, et non pas en tant qu'organe" (Lacan 2011: 17), a generation of psychoanalysts beginning with Catherine Millot, the infamous author of Horsexe (1983; trans. 1991), produced a series of texts stigmatizing transsexuals as very ill individuals (see Zabus \& Coad 2014:1). Turning its back on this tradition of interpreting transsexualism as a psychological illness, France was now leading the world in the attempt to normalize transsexuality. The governmental modifications to the medical nosology have even been understood as "part of an effort to re-imagine France as a harbinger of human rights around gender identity and orientation" (Sekuler 2013: 15-16). As if to confirm the status of France as a rights-protecting nation, Roselyne Bachelot, in 2014, conferred onto Marie-Pierre Pruvot the prestigious title of Chevalier de l'Ordre du Mérite. ${ }^{18}$

These two official announcements, both made in the early 2010s - Hollande's official apology and Bachelot's honorary gesture - show the French nation-state grappling with two of its demons: the Franco-Algerian past and the post-Lacanian transgender body, which is subsumed to the larger controversy around la théorie du genre, which led the then socialist French Government to abandon its program of promoting sex equality in schools and schoolbooks in 2014. ${ }^{19}$ Both micro-events hook up Jean-Pierre/Marie-Pierre Pruvot/Bambi's transgender status and her ambidextrous sexual and legal citizenship with "transpassing" across the sex/gender walls of both France and Algeria before and after the Algerian War and her transitioning to a full-fledged femininity in post-colonial France.

\section{THE INTERSEX OF ANGELS AND THE ISLAMIC SALVATION FRONT}

If Marie-Pierre Pruvot in Marie parce que c'est joli almost incarnates the events that led up to Algerian Independence, the intersex protagonist, Rhoulem, in Fériel Assima's Rhoulem ou le sexe des anges (1996), embodies the Civil War which sparked off the décennie noire. The Black Decade (1988-1998) is often said to have started

18 See https://www.bambi-officiel.com/bambi-chevalier-dans-lordre-national-du-merite/Accessed 21 December 2018.

19 https://www.lexpress.fr/actualite/societe/theorie-du-genre-ou-egalite-entre-les-sexes_1836853. html; Accessed 22 March 2019. 
with the riots of 4-5 October 1988 aiming to put an end to the ruling oligarchy of the FLN (Front de Libération Nationale) or the National Liberation Front, that had been the only ruling party since Independence.

The novel opens not with a mirror-birth, as in Pruvot's Marie, but with the birth of a child with its penis and, in lieu of testicles, labia minora and majora welded together. After splicing open the newly born baby's thighs, two women acting as witnesses - the mother and the midwife-discover with horror the child's "two sexes": "[...] quand on croyait en discerner un, on oubliait l'autre; quand on reconnaissait l'autre, la forme en était si étrange qu'on était plus sûr de rien" (Assima 1996: 7). The welding effect or suture is said to have spoiled (Fr: gâté, Assima 1996: 7) the fruit of this embryonic manhood, as fleshy labia replace the desired scrotum. The imagery of a spoiled, rotten fruit, destined to be unplucked points to a botched Genesis but also to penile dysfunctioning, a very sensitive issue in Maghrebi sexological discourse. ${ }^{20}$ Although classical Islamic discourse classified every human being as either male or female, it recognized the difficulty and often the impossibility to determine the body's "true genus" (Arabic: jins, also translated as "sex") (Sanders 1991: 74-95). Although jurisprudents have argued that medical technology can correct the manifestation of that genus, Rhoulem's intersex condition is never medicalized in Assima's novel.

An authorial statement confirms that it is God's will and it is the child's inescapable destiny (Fr: destin, Assima 1996: 9) — maktub, one would say in Arabic-, according to the twin tenets of divine will and predestination characteristic of Arab-Muslim cultures. God the Welder has decreed that Rhoulem would be "neither a girl nor a boy" and the child's secret is safe with the two women. However, the mother raises the child as a boy, for, she reasons, "[...] un homme peut avoir toutes les tares. Toutes lui sont pardonnées. Sauf une : qu'il ne soit pas un homme" (Assima 1996 : 10). The heralding of masculinity and, particularly, genital masculinity, as a superior category and the ensuing pressures on mothers to conceive boys is confirmed by Muslim feminist R. Hassan: "Generally speaking, the birth of a daughter is met with resignation and even sadness. A woman who only produces daughters is likely to be the target of harsh and abusive behavior and threatened with divorce" (Hassan 1991: 181). The father being written out of Assima's novel, Rhoulem is thus raised as a boy in a protective female environment, which finds its most palpable corollary in the friendly vapors of the women's hammam. But when he is nine, the prepubescent child's chest boasts two small mounds, on which the mother assiduously applies ice cubes to prevent them from growing.

20 For instance, the Association Marocaine de Sexologie organizes congresses every other year and most of the papers delivered at such Conferences, set in various cities in Morocco, are devoted to "dysfonctions érectiles." 
In the birth scene, the midwife, who, in most contexts, supervises and even monitors women's naked bodies (Mak 2012: 31), has decreed that one of the sexes might triumph over time: "Les deux sexes assemblés allaient se développer ensemble; le temps seul déciderait lequel triompherait de l'autre" (Assima 1996: 8). The triumph, however, is on the female side, as Rhoulem (which means "Treasure") starts displaying female secondary characteristics. The remainder of the plot is devoted to the repression of the feminine and the display of alpha-male violence. The war of the sexes is etched onto the infant's genitals and so is Algeria, torn by civil war (1991-2002), which opposed the Government and Islamist rebel groups. Tellingly, the growth of Rhoulem's intersexed body unfolds against a bleak sociopolitical canvas. Although the main location is the coastal city of Oran in Northwestern Algeria, the time period is non-descript. The reader of this account by an unnamed female omniscient narrator will however gauge a certain level of physical and psychical devastation following a military take-over, presumably by the FIS, and the razing of the slums around Oran. The specter of the FIS (Front islamique du salut) or the Islamic Salvation Front lingers over the novel but is only named late in the novel when an old woman asks Gabi, a young male lawyer living in her building: "Tu es du FIS? Eh, gamin, militaire? Entas FIS, ya ouled, askari" (Assima 1996: 158). The old woman's question in Arabic, tagged by French, reflects not only the degree of suspicion and discomfort between fellow tenants but also the obscurity of the Black Decade on account of the population's difficulty in identifying the actual perpetrators of terror (Crowley 2017: 7).

Although the spontaneity of the riots of October 1988 have been questioned, since members of the PAGS (Parti de l'Avant-Garde Socialiste) had been arrested and tortured ahead of the riots (Rahal 2017: 84-85), "Octobre noir" is alleged to have started on the night of 4-5 October 1988 in the working-class Bab el-Oued neighborhood by young rioters, who were afterwards "granted [...] the dignity of politically challenging the FLN régime" (Aï-Aoudia 2015: 31). A Sunni political party legalized as of 18 February 1989, the FIS as the main opposition party was elected in the local legislative elections (on 26 December 1991) after the Algerian Constitution was revamped to allow other parties besides the FLN to compete, thus moving Algeria from a single-party régime to a multiparty system. But the second round of elections was cancelled by the military coup in 1992, "thus ending the new-found experience of democracy" (Rahal 2017: 81). The dissolution of the FIS by the Army, which called for the resignation of President Chadli Bendjadid on 11 January 1992, led to the Civil War and the creation of the town-based GIA, that is, the Groupe islamique armé or the Armed Islamic Group in $1994,{ }^{21}$ which

21 The Islamic Armed Movement or MIA (Mouvement islamique armé) was based in the mountains. The MIA then joined other groups to become the FIS-loyalist Islamic Salvation Army. 
carried out arbitrary attacks against civilians. The FIS then attempted to build an Islamic state based on sharia law, which entailed, among others, the strengthening of Islamization programs initiated by President Houari Boumediene (1965-1978) in the aftermath of independence (see Crowley 2017:5); Arabization accompanied by anti-French language policies; and sex segregation in public spaces. In addition to the Islamists' casting of women activists as mécréantes (un-believers; Rahal 2017: 90), the imposition of the veil for women turned "white Algiers" "black," as Mohamed Laïd Athmani poetically put it in "L'Après-octobre noir" (Athmani 2012: 33).

Assima captures this era of political upheaval and unchecked violence, the publication of her novel in 1996 testifying to events preceding the 1997 ceasefire and its ensuing "series of amnesties" (Le Sueur 2010: 9). Assima enshrines the Black Decade and, in particular, the Civil War, not only as the war against women, what Wassyla Tamzali has called "la guerre contre les femmes" (Tamzali 2007: 174), but also as the war against the feminine, here presented as repressed in Rhoulem, the intersex individual.

In this semi-autobiographical novel, the French casques bleus (Assima 1996: 122) are evoked as a friendly support group that will put an end to the bomb-dropping and the general insecurity, as they are part of the United Nations Peacekeeping forces. The ghost of Mlle Yvonne, an old French lady rumored to be of Jewish ancestry and the owner of a sewing workshop, is conjured up early in the novel, as she had the reputation of having had affairs with "des commandos français" (Assima 1996: 18) based in Oran. The presence of French Special Forces points to the tensions between France and the GIA and other insurgent groups in the mid1990s. Indeed, in 1993, under Charles Pasqua as Interior Minister, the French Government had launched a counterterrorist Operation (Chrysanthemum) within France, as a retaliation against hostage taking in Algiers, and in 1994 the Chalabi network supporting Algerian resistance had been dismantled (Foley 2013: 293). Jeremy Shapiro writes about the unfolding of events thereafter:

Apparently, in response, on Christmas Day 1994, an Air France flight from Algiers to Paris was hijacked. With this hijacking, the GIA announced its ability and desire to strike directly on French soil. The GIA demanded the abandonment of French aid to Algeria and financial reparations for the damages inflicted on Algerians by France between 1945 and 1962 before it would release the plane. ... Expecting further attacks, French authorities decided to increase the pressure on Islamist networks in France. (Shapiro 2007: 143).

Amidst chaos and retaliatory moves culminating in the GIA's orchestration of murders in 1995, French citizen Mlle Yvonne disappeared in mysterious 
circumstances and joined the ranks of the 7000 or so "disappeared" who were taken and, it is presumed, killed (see Crowley 2017:7, Footnote 5). She left behind a disused sewing workshop, where she had taken under her wings rejected, pregnant rural girls, until they turned sixteen and were marriageable.

Soon after the disused workshop's reopening, Rouhlem's mother gave him up for adoption to the workshop's new Head. The routine at the sewing workshop was disrupted one day, when a dance was organized and Ginane, an elderly woman, in a trance, modeled a male organ out of her skirts and the girls rubbed themselves against it with a trance-like passion; in their frenzy, they summoned Rhoulem, called the severed man (Fr: "l'homme coupé," Assima 1996: 39). Rhoulem is further humiliated when the spinner discovers him in the utility room, binding his breasts, and thereby repressing the feminine in a fundamentalist gender regime of femininities and masculinities in crisis.

In foregrounding an intersex individual raised as a boy, Assima is in perpetual dialogue and counterpoint with Moroccan Tahar Ben Jelloun's L'enfant de sable (1985) and its sequel, La nuit sacrée (1987), both written approximately one decade earlier and often read as the parallel search for the roots of gendered identity and of national identity. All three novels-Ben Jelloun's two novels and Assima's Rhoulem - foreground the return of female repressed biology. L'enfant de sable is the story of the eighth child, Ahmed, who, born female, is raised as a boy to comfort the father who has been parenting seven daughters. Upon his father's death, he starts to live as a woman. As Zahra, he is employed by relatives in a circus sideshow, where he is disguised as a man during the first part of the show and as a femme fatale in the second (Ben Jelloun 1985: 91; 121). About this "continued unmasking of cross-dressing," Jarrod Hayes remarks that "Ahmed repeatedly reveals his/her history of dressing and passing as a man on the stage of the freak show. [...] Performing woman, in this vision of gender, means doing so for the profit of a pimp" (Hayes 2000: 169), which is not without recalling some of the Parisian transformistes' gilded prostitution in the 1950s.

The sequel, La nuit sacrée, told in the first person by Zahra herself, comes closest to Assima's novel, in that it features a similar scene, yet in counterpoint, where the protagonist unbinds her breasts. Here the fettered female body is rid of its cords and strings which get unraveled, thereby liberating the woman cast in the "wrong" gender in the process: "Je faisais mes premiers pas de femme libre" (Ben Jelloun 1987 :45). This exemplar of unbinding and figurative unveiling finds an a contrario act of binding in Roublem since he is seen binding his breasts as if he were bandaging a wound-"comme s'il pansait une blessure" (Assima 1996: 47). This literal veiling of Rhoulem's female forms during this voyeuristic discovery will trigger off his flight and subsequent tribulations as the victim of 
several rapes and as a prostitute working for a pimp, thereby marking him, like Ahmed/Zahar in Ben Jelloun's novels, as a woman despite his living as a man.

Taking his cue from Sharon Marcus's insights into the male rapist's casting of his victim as a woman but also into his imprinting "the gender identity of 'feminine victim' on his target" (Marcus 1992: 386), Hayes builds on the "rape script," which points to the violence with which "gender is stamped onto bodies" (Hayes 2000: 175); Hayes concludes that compulsive heterosexuality is performed as contiguous with rape and prostitution. Like Ahmed/Zahra in Ben Jelloun's novels, Rhoulem is subjected to the "rape script." When escaping aboard a truck, Rhoulem is forced to endure the truck-driver Hakim's molestations and the gurgling of Hakim's semen in his throat while he feebly protests twice: "Je n'ai pas de sexe" (Assima 1996: 51, 52). On another day, Hakim forces him to wear women's clothes; Rhoulem goes through the motions in the hope of leaving Oran and going to Algiers, where he is eventually dropped off in a half-constructed building where he is hosted by a man, Bazouz. At this point, the novel tips into another series of destructive encounters, as the self-designated "sexless" Rhoulem meets the castrated Bazouz.

The disfiguration of male genitals is not innocuous in that it reflects the mutilation of the post-independent nation-state and the resulting psychological split or Spaltung created by the GIA Army and the FIS, which patrol Algeria's cities, respectively "by day" and "by night," as Assima puts it in her previous novel Une femme à Alger : Chronique du désastre (1995: 184). The alleged sexlessness of Rhoulem, under which Assima dissimulates his intersex status, is likened to the conventionally genderless angels in the body of the text, and its subtitle-"le sexe des anges"-, as well as in its subtext. The subtext tells the story of a God-sent angel who comes to the rescue of the two progenies (resulting from the Sultana's rape by a "eunuch"), by gluing them to each other (Assima 1996: 77). In the Qur'ān, angels are said to be God's "messengers" endowed with "two, three or four pairs of wings" (Koran/ Qur'ān 35:1) and, as God's most obedient creatures, predated the creation of Adam. In a Hadith in which God has a conversation with Gabriel/Djibril, there is an allusion to angels' ability to take on various forms (alKisāi 1997: 13-14), perhaps, as De Sondy ventures, "as humans comport themselves as masculine and feminine" (De Sondy 2015: 97-98). While being angelic or sacred is often linked to not being clearly gendered or to androgyny, as was the case in European nineteenth-century narratives (Mak 2012: 86), Assima's casting of Rhoulem as an ambisexual angel may be read as her endorsement of a pre-Adamic Islamic masculinity. Her endorsement of an "angelic" masculinity goes along with her questioning of Islamist fundamentalist masculinities, such as those of the FIS and the GIA, as well as their hypocrisy: "Race d'obsédés. Ça menace au nom de l'Islam et ça viole dans les maquis"(Assima 1996: 39), the word 
maquis not so innocently conjuring up the French resistance movement against German occupation.

The castration of Bazouz, Rhoulem's host, results from a settling of accounts by a tyrannical army figure called the "Commandant," whose strategy of terror duly recalls that of the FIS and the GIA. The "Commandant" has indeed instigated the atrocious mutilation by having Bazouz's testicles wretched out with a broken bottle neck: "La verge a disparu dans un magma de viande séchée, brûlée. ... Un lambeau de chair pend à la place des testicules arrachées» (Assima 1996: 85). The disappearance of Bazouz's penis in a crater of dried, burnt meat suggests a forcible castration followed by cauterization. The flap of flesh hanging in lieu of testicles recalls Rhoulem's labia which ousted the scrotum in the inaugural birth scene. The reason for such mutilation lies in Bazouz's illicit affair with a young seamstress, whose husband (paralyzed from the waist down) gave the Commandant a substantial sum to get rid of him. The hobbling Bazouz thus harbors dreams of revenge against the Commandant whereas Bazouz's lover cried so much after her lover's castration that she partially lost her eyesight and ended up sewing evening gowns in a brothel.

Assima takes care to cast the Commandant as the ultimate symbol of male authority and its heteronormative impunity, which is, she seems to imply, characteristic of both the GIA Army and the FIS, which she twins as oppressors in her novel Une femme à Alger (Assima 1995: 184). Not only is the Commandant content with castrating Bazouz but he also turns the latter's impotence into a form of sadistic torture, as he orders Bazouz to whip his guest Rhoulem and lacerate his feet, a warning against the possibility of escape, as Rhoulem is conditionally hired in Zino's bar as a performer. Zino's bar is a knotty microcosm of sexual exploitation and harassment, which confirms Hayes's intuition that "woman" as a category is always already read as synonymous with rape and prostitution. One night, Rhoulem witnesses, unobserved, an obese young man being hanged and gang-raped by his work mates but one of the men hesitates:

«Je peux pas, je l'ai jamais fait avec ...»

«... un homme ? C'est çà hein ? Parce que pour toi, c'est un homme, cet animal ? On est des pédés, alors, d'après toi ? Des pédés ? Tu préfères les femmes! Tiens, et comme ça, tu peux toujours pas te la faire, cette femme!» (Assima 1996: 74).

It turns out that this blob of flesh is the baker's son who is mentally challenged and is construed as a "woman" in this constructivist version of the sex binary and therefore passive (or rendered passive) and penetrable by penetrators whose status as heterosexual men is left undisturbed. 
Even though intersex or, by his own reckoning, both "sexless" and "genderless," Rhoulem is likewise construed as a woman, as he is sexually assaulted every night and is offered asylum in the female dancers' headquarters, where Azria, the female lead singer, with whom he will partner as a dancer in a duo, takes pity on him and offers him protection. This artistic duo, as in Ben Jelloun's L'enfant de sable, is complementary in anatomical terms as well, for, contrary to Rhoulem who has breasts but binds them, Azria appears to have no breasts. The flat-chested Azria undoes Rhoulem's bandage, sucks his breasts, and lovingly feels the dry and coarse skin of his crotch: "Ses doigts remontent encore comme pour dessiner cette forme nouvelle, inachevée" (Assima 1996: 81). This incomplete form is the ambisexual site of Rhoulem's gender. One evening, Rouhlem bursts out : «Azria, si Dieu m’avait donné dêtre un homme, je t'aurais aimée comme une sainte» (Assima 1996 : 87). The impossibility of the enactment of that fantasy is followed by Azria advising him to leave for fear of the repercussions of the Army finding him there. Strategically, the specter of the GIA is revived every time the heteronormative nation-state feels threatened.

The continued casting of Rhoulem as a woman-that is, a passive object of penetration and denigration-is confirmed in one of the last scenes in the novel. After a failed search for Rhoulem in Algiers, the reader is told that Gabi the lawyer, who is willing to take up Rhoulem's defense, leads him for a blow job to a Christian cemetery and then contemptuously pees on Rhoulem's body in a tomb while expressing his horror: "J'ai couché avec une putain!" (Assima 1996: 149). Assima's exposure of male sexual hypocrisy follows upon an earlier moving passage reflecting on how female victims of rape are shamed and end up in brothels or die as a result of self-abortion (Assima 1996: 129). In the above passage, Rhoulem's figurative entombing in a Christian cemetery outside of the Islamic faith prefigures Rhoulem's end, which crowns the novel but not before the Islamists meet their appropriate end and Rhoulem moves from victimhood to agency.

In Zino's bar, Rhoulem assaults the Commandant with a broken bottle-neck in retaliation against the Commander's castration of Bazouz. But Rhoulem's feeble attempt fails and the Commandant exposes to the crowd Rhoulem's condition as the only hermaphrodite of the whole human species: "Le seul hermaphrodite de toute l'espèce humaine ! ... Il n'a rien sous son pagne: ni le poil fin d'une femme, ni le poil dru d'un homme. Et sa mère l'a bien nommé, puisque c'est le seul trésor (the meaning of Rhoulem is «treasure») dont on peut profiter sans avoir à se faire pardonner! Dieu ne lui a même pas fait l'honneur dêtre une putain!» (Assima 1996: 153; my addition). In response, Rhoulem hurls the broken bottle at the Commandant and opens a gash in the latter's belly before he then willingly exposes his own ambiguous genitals: "il découvre la flétrissure 
camouflée de sa chair. Sexe mutilé qui renie ses deux lobes embrassés. Les testicules, atrophiés, s'affrontent dans un enfoncement vain. Motte à la tige réfugiée, endormie, portée par un corps qui danse. Ici, l'orgueil de l'homme fait silence" (Assima 1996: 154). The Commandant and his men catch up with the exposed Rhoulem on the run and stab him to then leave him in front of Gabi's building, where Gabi picks up the body and calls the police, but to no avail in this lawless nation-state. The Commandant is then found with his head stuck between two stones with poultry blood drying in his mouth, which intimates that one of his orifices, his mouth, was violated and that he choked as a result. While Rhoulem's razed genitals point to a cityscape ravaged by civil war, the Commandant's quasi-decapitation and symbolic political emasculation signifies the end of what Dja Zairi has termed "the reign of the cacti" (Zairi 2008: 139), a metaphor used to refer to bearded Islamists. More largely, the Commandant's death signals the temporary suspension of Algeria as a nation-state masquerading as an impregnable theocracy.

The cut or rather atrophied penis in Rhoulem and the testicles wretched out in Bazouz, that is, the disappearance of male genitals and their corollary impotence reveal utopias about the extinction of exacerbated masculinities and entail the end of the fundamentalist nation-state that can no longer en-gender itself as male and reproduce itself. The circle of violence, however, perpetuates itself, as Rhoulem is found wounded after Bazouz has shoved a poker into him because he could not rape him. This anal defilement recalls a scene in Christopher Marlowe's homoerotic play Edward II and, closer to us, Derek Jarman's Queer Edward II, where a red-hot poker is shoved into Edward II's bowels. Rhoulem becomes the ultimate insertee whose rectum is "a grave" (Bersani 1987: 197222). His death by hemorrhage in Oran points to a war-torn Algeria leaking with endless streams of blood while Bazouz, the castrated man, turns his anger against a fellow-victim rather than the Islamist oppressor.

In his death, Rhoulem moves from being an angel to a glittering star, now part of the celestial bodies: "Les étoiles roulent dans leur lumière comme des perles sur un fil d'or" (Assima 1996: 175). Contrary to Nedjma in Kateb Yacine's eponymous, anti-colonial allegory Nedjma (1956), Rhoulem is not "a star of blood sprung from murder to obstruct vengeance" (Yacine 1991: 239-240). In 1956, the "star of blood" augured the blood bath in which the new Algerian nation was to be born. Yet, Rhoulem shares with Nedjma a past of rape and violence, which, in this case, culminates with the rape of the sexless angel and, by the same token, the senseless violence of the Black Decade, a violence which was going to be quenched within two years of the publication of Fériel Assima's dystopic novel. 


\section{CONCLUSION}

Both Jean-Pierre Pruvot's transgender body and Rhoulem's intersex body are defined by social constructions of their genitals and of their repressed femininity in a sociopolitical context wrought with tensions between France and Algeria during pre-independent and post-independent times or within Algeria during the Civil War and the Black Decade. Both texts host an inaugural birth scene, that determines the fate of the transgender or intersex bodies, which transmuted into a transwoman and a sexless angel, respectively, point to Algeria's failed erection of the nation-state as male and its flawed governmentality.

Foucault's analysis of governmentality as "government practices that monitor and shape individuals' conduct" leaves the portal open to "as yet unforeseen kinds of relationships" (Burchell et al 1991: 87). These "unforeseen relationships" are bound to affect notions of citizenship conceived as "gradations of esteem ... with respect to the way the state conceives, represents, polices, educates, defines, criminalizes and taxes what its various agencies take to be 'sexuality' or sexualities" (Carver 1998: 14). Against such a Foucauldian discursive canvas, Jean-Pierre Pruvot's life as a privileged pied-noir in colonial Algeria and then as a second-class citizen and passing MTF in France helps articulate the role played in citizenship and nation formation by both the return-migrant, transnational body and the transitional body, as it migrates from one gender to another, from one country to another. Once in France, Marie-Pierre Pruvot aka Bambi, a transformiste in the Parisian cabaret subculture of the late 1950s, becomes a "partial citizen" in the sense in which, like gays and lesbians, she is "excluded from the construction of 'nation' and 'nationality"' (Robson \& Kessler 2008: 541). Being a "sexual migrant" or rather a trans migrant, that is, an individual who migrates because of his/her transgender status, Pruvot brings added nuance to the necessity of transcending the France-Algeria binary and of embracing the fluidity and, by the same token, the futurity of gender diversity, as it shapes "unforeseen relationships."

Conversely, Rhoulem's intersex body and repressed femininity reflect the Civil War and the aporias of Islamist nation-building during the Black decade. If sexual citizenship entails the relationship between the state and its sexualized citizens, it is also true that sexual identities are regulated by the state. However, Rhoulem and the "doubting sex" paradigms around his "angelic" status show that the state in the person of the Commandant cannot control his dissidence. Yet, Rhoulem as a "sexual migrant" cannot enjoy staying in any specific location (Oran, Algiers) and cannot leave Algeria, that is, home, in order to find a "queer home" outside of its borders (Binnie 1997: 240). He therefore cannot enjoy "the popularity of travel" that Pruvot, for instance, experienced. Therefore, the only escape for Rhoulem is death. Yet, this anti-archive of death, this anarchic space of forgetting, can spur 
what Jacques Derrida has called "an archive fever," a will to memory, which has "both conservative (literally) and revolutionary potential" (Derrida 1998: 10). Rhoulem's death is therefore double-edged, all the more since it is accompanied by the author's implicit mourning, and the very notions of memory and commemoration are often the motors of national belonging.

Laura Briggs et al have suggested that 'transnationalism' can do to the nation what gender did for sexed bodies: provide the conceptual acid that denaturalizes all their deployments, compelling us to acknowledge that the nation, like sex, is a thing contested, interrupted, and always shot through with contradiction" (Briggs, McCormick, and Way 2008: 627). These insights into the interdependency of transnationalism and transgenderism are bound to erode the naturalness of national and sexual paradigms. Transing the nation therefore points the way to transcending binaries such as the sex/gender divide and embracing forgetfulness. Such a "transing" of the Algerian nation is a necessary rite of passage to move beyond the Franco-Algerian affaire de famille through engaging in "unforeseen relationships" outside of family, tradition, and lineage and thus enter the post-mourning phase.

\section{REFERENCES}

Aït-Aoudia, Myriam. «La Naissance du Front Islamique du Salut : une politisation conflictuelle (1988-1989).» Critique internationale, Vol.30, No1, 2006, pp. 129-144. Al-Kisāi, Muhammad Ibn Abdullah. Tales of the Prophets. Trans. W. M. Thackston Jr. Chicago: Kazi Publications, 1997.

Anderson, Benedict. Imagined Communities: Reflections on the Origin and Spread of Nationalism. London : Verso, 1983.

Aron, Robert. Histoire des Années 40. Paris : Libraire Jules Tallandier, 1976.

Ashley, April \& D. Fallowell. April's Odyssey. London: Jonathan Cape, 1982.

Assima, Fériel. Une femme à Alger : Chronique du désastre, Paris : Arléa, 1995.

-----. Rhoulem ou le sexe des anges. Paris : Arléa, 1996.

Athmani, Mohamed Laïd (2012). «L'après octobre noir in La décennie noire en

Algérie : 1988-1998 (Recueil de Poèmes).» Paris : Edilivre, 2012.

Ben Jelloun, Tahar. L'enfant de sable. Paris : Seuil/ Coll. Points, 1985.

-----. The Sand Child. Trans. Alan Sheridan. New York: Ballantine, 1987.

-----. La nuit sacrée, Paris : Seuil, 1987.

-----. The Sacred Night. Trans. Alan Sheridan. San Diego: Harcourt Brace Jovanovich, 1989.

Bersani, Leo. "Is the Rectum a Grave?" AIDS: Cultural Analysis/Cultural Activism, Vol. 43, Winter 1987, pp. 197-222. 
Bhabha, Homi K. Nation and Narration. London: Routledge, 1990.

Binnie, J. "Invisible Europeans: Sexual Citizenship in the New Europe." Environment and Planning, Vol. 29, 1997, pp. 237-248.

Bouraoui, Nina. Garçon manqué, Paris: Stock, 2000.

Bouraoui, Nina. Tomboy. Trans. Marjorie Attignol Salvodon \& Jehanne-Marie Gavarini. Nebraska: Bison Books, 2007.

Briggs, Laura, Glady Mccormick, and John T. Way. “Transnationalism: A Category of Analysis." American Quarterly, Vol. 60, No 3, 2008, pp. 621-637.

Burchell, Graham, Colin Gordon, and Peter Miller, eds. The Foucault Effect: Studies in Governmentality with Two Lectures by and an Interview with Michel Foucault. Chicago: University of Chicago Press \& Hemel Hempstead: Harvester Wheatsheaf, 1991.

Caruth, Cathy. Unclaimed Experience: Trauma, Narrative, and History. Ithaca: Cornell University Press, 1996.

Carver, Terrell. "Sexual Citizenship: Gendered and De-Gendered Narratives." In Politics of Sexuality: Identity, Gender, Citizenship, eds. Terrell Carver \& Véronique Mottier, London \& New York: Routledge, 1998. Pp. 13-24.

Cerdan, Alexandra, and Betty Peyrade. Transsexuelle et convertie à l'Islam. Monaco : Alphée, 2010.

Crowley, Patrick. "Introduction - Algeria: Nation, Culture, and Transnationalism 1988-2015." In Algeria: Nation, Culture, and Transnationalism 1988-2015. Ed. Patrick Crowley. Liverpool University Press, 2017. Pp. 1-19.

De Sondy, Amanullah. The Crisis of Islamic Masculinities. London \& New York: Bloomsbury, [2013] 2015.

Derrida, Jacques. Archive Fever : A Freudian Impression. Trans. Eric Prenowitz. Chicago : Chicago University Press, 1998.

Espineira Karine, Maud-Yeuse, Thomas, Arnaud, Alessandrin. La Trans-yclopédie. Paris : Éditions des Ailes sur un Tracteur, 2012.

Foerster, Maxime. Elle ou lui ? Une histoire des transsexuels en France. Paris : la Musardine, 2012.

Foley, Frank. Countering Terrorism: Institutions, Norms and the Shadow of the Past. Cambridge University Press, 2013.

Foucault, Michel. Power. Ed. James D. Faubion. New York: New Press, 2001.

-----. "Lecture 11 of 17 March 1976." Society Must Be Defended. Lectures at the Collège de France, 1975-1976. Trans. D. Macey. Harmondsworth: Penguin, 2003.

Gershovich, Moshe. "Stories on the Road from Fez to Marrakesh: Oral history on the Margins of National Identity." Nation, Society and Culture in North Africa. Ed. James McDougall. Frank Cass, London \& Portland, Oregon: Frank Cass, 2003. 
Hall, Radclyffe. The Well of Loneliness. London: Virago, [1928] 1987.

Hassan, R. "The Issue of Woman-Man Equality in the Islamic Tradition." In Women's and Men's Liberation-Testimonies of Spirit. Eds. L. Grob, R. Hassan, and H. Gordon. Westport, CT: Greenwood Press, 1991. Pp. 65-81.

Hayes, Jarrod. Queer Nations: Marginal Sexualities in the Maghreb. Chicago: The University of Chicago Press, 2000.

Hobbes, Thomas. The Leviathan/ Or The Matter, Forme, Eo Power of a Common-Weath Ecclesiasticll and Civill. London: Andrew Cooke, 1651 https://socialsciences.mcmaster.ca/econ/ugcm/3113/hobbes/Leviathan.pdf. Accessed 21 December 2018.

Klein, Norman. The History of Forgetting: Los Angeles and the Erasure of Memory. London: Verso, 1997.

Koran (The). Translated with notes by N. J. Dawood. London: Penguin Books, 2003.

Lacan, Jacques. Le Séminaire Livre XIX ... ou pire. Paris: Seuil, 2011.

Le Sueur, James D. Algeria since 1989: Between Terror and Democracy. New York \& London: Zed Books, 2010.

Leftah, Mohammed. Au Bonheur des limbes. Paris, La différence, 2006.

Lifshitz, Sébastien. Bambi (documentaire). Un monde meilleur, Epicentre films \& Canal+, 2013, 57, 24 mins. https:/www.youtube.com/watch?v=ZjmnLEJSI-I. Accessed 22 December 2018.

Mak, Geertje. Doubting Sex: Inscriptions, Bodies and Selves in Nineteenth-century Hermaphrodite Case Histories. Manchester: Manchester University Press, 2012.

Marcus, Sharon. "Fighting Bodies, Fighting Words: A Theory and Politics of Rape Prevention." In Feminists Theorize the Political. Eds. Judith Butler and Joan W. Scott. New York: Routledge, 1992. Pp. 385-403.

Morris, Jan. Conundrum. New York: New York Review Books, [1974] 2002.

Najmabadi, Afsaneh. "Transing and Transpassing Across Sex-Gender Walls in Iran.” Women's Studies Quarterly, Vol 36, No 3-4, 2008, 23-42.

Nietzsche, Friedrich. "Second Essay: Guilt, Bad Conscience, and the Like." Iin On the Genealogy of Morals. A Polemic. New York: Vintage, 1969. Pp. 57-96.

Prosser, Jay. Second Skins: The Body Narratives of Transsexuality. New York: Columbia University Press, 1998.

Prosser, Jay. “'Some Primitive Thing Conceived in a Turbulent Age of Transition': The Transsexual Emerging from The Well." In Palatable Poison: Critical Perspectives on The Well of Loneliness. Eds. Laura Doane and Jay Prosser. New York: Columbia University Press, 2001. Pp. 129-144.

Pruvot, Marie-Pierre. Marie parce que c'est joli. Paris : Bonobo, 2007.

Pruvot, Marie-Pierre. J'inventais ma vie. Plombières-les-bains : Ex Aequo, 2010. 
Pruvot, Marie-Pierre. France, ce serait aussi un beau nom. Plombières -les-bains : Editions Ex-Aequo, 2011.

Rahal, Malika. "1988-1992: Multipartism, Islamism and the Descent into Civil War." In Algeria: Nation, Culture, and Transnationalism 1988-2015. Ed. Patrick Crowley. Liverpool University Press, 2017. PP. 81-99.

Raun, Tobias. Out Online: Trans Self-Representation and Community Building on YouTube. New York: Routledge, 2016.

Reeser, Todd W. "Introduction" and "TransFrance," In Transgender France. L'Esprit créateur, VoL. 53, No 1, Spring 2013, pp. 1-3; 4-14.

Renan, Ernest. "What's a Nation?" In Nation and Narration. Ed. Homi K. Bhabha. New York: Routledge, 1990. Pp. 8-22.

Robson, Rutharn and Tanya Kessler. "Unsettling Sexual Citizenship." McGill Law Journal/Revue de droit de McGill, 53, 2008, pp. 537-571.

Rubin, Gayle. "Thinking Sex: Notes for a Radical Theory of the Politics of Sexuality." In The Lesbian and Gay Studies Reader. Eds. H. Abelove, M.A. Barale, D. H. Halperin. London: Routledge, 1993. Pp. 3-44.

Sanders, Paula. "Gendering the Ungendered Body: Hermaphrodites in Medieval Islamic Law." In Women in Middle Eastern History: Shifting Boundaries in Sex and Gender. Eds. Beth Baron and Nikki Keddie. New Haven: Yale University Press, 1991.

Sekuler, Todd.. "Convivial Relations between Gender Non-Conformity and the French Nation-State.” L'Esprit créateur, Vol. 53, No 1 (Spring 2013), pp. 15-31. Serhane, Abdelhak. Messaouda. Paris: Points, [1983] 2002.

Shapiro, Jeremy. "France and the GIA." In Democracy and Counterterrorism: Lessons from the Past. Eds. Robert J. Art and Louise Richardson. Washington, D.C.: Endowment of the United States Institute for Peace, 2007. Pp. 133-167.

Stora, Benjamin. La Grangrène et l'oubli : la Mémoire de la Guerre d'Algérie. Paris : La découverte, 1998.

Stryker, Susan and Nikki Sullivan. "King's Member, Queen's Body, Self-Demand Amputation and the Somatechnics of Sovereign Power." In Somatechnics: Queering the Technologisation of Bodies. Eds. Nikki Sullivan, Samantha Murray. Farnham and Burlignton : Ashgate, 2009. Pp. 49-64.

Tahir, Hicham. Jaabouq. Rabat : Casa Express Editions, 2013.

Taïa, Abdellah. Le jour du roi. Paris : Seuil, 2010.

Tamzali, Wassyla. Une éducation algérienne : de la Révolution à la décennie noire. Paris: Gallimard/Coll. Témoins, 2007.

Vassallo, Helen. "Unsuccessful Alterity? The Pursuit of Otherness in Nina Bouraoui's Autobiographical Writing." International Journal of Francophone Studies, 2009, 12.1: 37-53. 
Yacine, Kateb. Nedjma. Transl. Richard Howard. Charlottesville: University Press Virginia, [1956] 1991.

Zabus, Chantal and David Coad. "Introduction."In Transgender Experience: Place, Ethnicity, and Visibility. New York and London : Routledge, 2014. Pp. 1-16.

Zairi, Dja. Le temps des cactus : Algérie décennie noire : roman. Paris : Société des Ecrivains, 2008.

Zaganiaris, Jean. "Informal Interview with Abdellah Taïa." Institut français de Casablanca, Morocco, 12 June 2008.

Chantal Zabus

Université Paris 13-Sorbonne Paris Cité, czabus@hotmail.com



\section{Proces spolnega prehajanja v alžirski nacionalni državi: tekstovna transspolnost ter interspolnost od obdobja pred samostojnostjo do črnega desetletja}

Članek raziskuje vlogo transspolnosti in interspolnosti v dveh ključnih tekstih (Marie-Pierre Pruvot Marie parce que c'est joli (2007) in Fériel Assima Roublem ou le sexe des anges (1996), ki oba predstavljata kroniki dveh pomembnih obdobij alžirske zgodovine, dveh desetletij, ki sta vodili do alžirske samostojnosti leta 1962 ter t.i. črno desetletje v letih 1988-1998.

Ključne besede: nacionalna država, transspolnost, Alžirija, interseksualnost, magrebski kvir 